\title{
PLATE COAGULASE AND FIBRINOLYSIN TESTS FOR STAPHYLOCOCCI
}

\author{
BY \\ C. H. LACK \\ From the Department of Pathology of the Institute of Orthopaedics and the Roval National Orthopaedic \\ Hospital, London
}

(RECEIVED FOR PUBLICATION JUNE 19, 1956)

The two plate methods to be discussed have been described before, but attention is drawn to some useful modifications which may make them more serviceable for bacteriological surveys. Some implications of the proteolytic activity of staphylococci are also considered.

\section{"Coagulase Plates"}

When human blood bank plasma is mixed with nutrient agar in a concentration of about 12 to $15 \% \mathrm{v} v$ and poured into Petri dishes at a temperature of $45^{\circ} \mathrm{C}$. the mixture sets as a clear gel. Staphylococci inoculated on to this medium develop opaque haloes around the colonies in 12 to 48 hours if they produce coagulase (Lack and Wailling, 1954). The advantages of the plate method are that mixtures of coagulase-positive and negative staphylococci may be sorted out on primary culture, and that highly fibrinolytic staphylococci, which may dissolve their coagulase clots in the test-tube during an overnight incubation, ate less likely to be overlooked on the plate. The disadvantages of this method as originally described are that it may take more than 12 hours to detect coagulase, and that some batches of bank plasma are unsuitable by reason of their low fibrinogen content.

Human fibrinogen alone is satisfactory, as it is always contaminated by the requisite co-factor, but it is too scarce; commercial bovine fibrinogen is too deficient in co-factor to use alone. But bovine fibrinogen combined with a source of co-factor provides an excellent substrate for the platecoagulase test, and the first section deals with the results of plate tests using different commonly available plasmas or sera to supplement bovine fibrinogen.

\section{"Fibrinolysin Plates"}

In the plate method for detecting fibrinolysis by staphylococci, first described by Christie and Wilson (1941), nutrient agar is melted and cooled to about $50^{\circ} \mathrm{C}$, $12 \%$ oxalated plasma is added. the mixiure heated at $56^{\circ} \mathrm{C}$. for 10 to 15 minutes in order to precipitate the fibrinogen, and plates are poured. This medium is opaque, and fibrinolytic colonies of staphylococci produce zones of clearing around them in 24 to 48 hours.

This original method was used in a survey of staphylococci and the unreliability of some batches $\mathscr{C}$ of human bank plasma again encountered. Diges- . tion of fibrin clots by staphylococci is, in the main, brought about by the activation of plasminogen in the plasma by a kinase produced by the staphylococci; there is evidence that some strains produce a spesific protease in addition. So $\underset{2}{\mathscr{Q}}$ in this test, as in the coagulase test, the plasma or $\overrightarrow{\vec{B}}$ fibrinogen must have an additional factor, in this $\frac{0}{3}$ case plasminogen, and again commercial bovine fibrinogen is deficient. By using bovine fibrinogen? as the substrate and adding a small amount of a응 suitable plasma or serum to provide the plasminogen, a better result is obtained than by using human 3 plasma alone. However, the plasmas and sera. commonly available all contain a measure of $\frac{\circ}{3}$ plasmin inhibitor which retards the appearance of 0 fibrinolysis and may even suppress it altogether.? When this inhibiior is removed by chloroform, less $\frac{D}{0}$ plasma or serum is required and the fibrinolytic colonies may be detected in 12 hours or less. N

\section{Materials and Methods}

The nutrient agar used throughout these tests was $\omega$ supplied by the Southern Group laboratories and $10 \mathrm{ml}$ was used for each plate.

It is immaterial whether the plasma is citrated. oxalated, or heparinized, or whether it is a month or two old. When plasmas and sera are compared the serum has been obtained from the homologous plasma움 by the addition of thrombin.

To remove plasmin inhibitor $1 \mathrm{ml}$. of chloroform is shaken with $10 \mathrm{ml}$. plasma or serum and allowed to stand for 20 minutes. The inhibitor is in the precipitate and the supernatant is used after centrifugation. 
The bovine fibrinogen, Armour's bovine plasma fraction $I$, is dissolved in distilled water and sterilized by Seitz filtration, or it may be sterilized as a powder by irradiation. It is used in a final concentration of about $0.2 \%$. Seitz-filtered fibrinogen solution usually clots spontaneously after a few hours, so must be freshly prepared; it may be stored in the deep-freeze cabinet.

The soybean trypsin inhibitor used to inhibit plasmin was obtained from Dr. M. Kunitz, but may be purchased from the Worthington Biochemical Sales Company, New Jersey. A knife point of the powder was shaken up with $10 \mathrm{ml}$. distilled water, brought carefully to the boil, and used in a concentration of $0.5 \mathrm{ml}$. per plate.

For "coagulase" plates, the melted agar, plasma or serum, and bovine fibrinogen are all stood in a waterbath at $45^{\circ} \mathrm{C}$. until they are at the same temperature; they are then mixed in the proportions of $10 \mathrm{ml}$. agar, $1 \mathrm{ml}$. plasma or serum, and $1 \mathrm{ml}$. of $2.5 \%$ bovine fibrinogen; the mixing is done in bulk for a large number of plates or in warm Petri dishes if only for a few. The mixture must be allowed to set and dry before inoculation. Swabs or cultures are then streaked out; haloes around colonies may be seen after overnight incubation at $37^{\circ} \mathrm{C}$. Cultures are best tested by inoculation with a straight wire (Fig. 1).

For "fibrinolysin" plates, the digest agar, the plasma or serum, and the bovine fibrinogen solution are used in the same proportions but are kept at $56^{\circ} \mathrm{C}$. for 20 minutes before pouring into Petri dishes.

\section{Results}

The results of " coagulase" plates prepared with different combinations of fibrinogen, plasma, and sera, are set out in Table I. It will be seen that human, rabbit, or horse serum will do in place of plasma as a source of co-factor, and human serum may be diluted 1:50 in saline and still give satis-

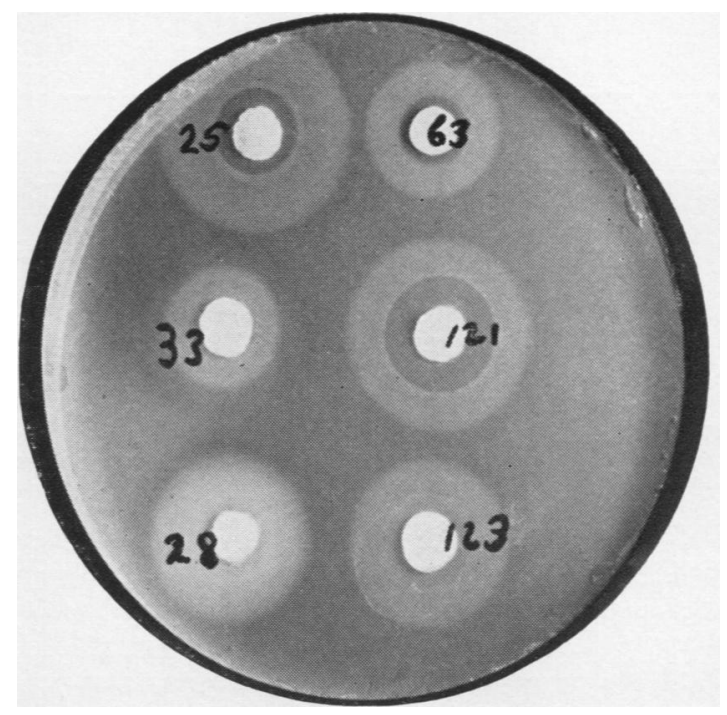

FIG. 1.- "Coagulase zones" around colonies of different strains of staphylococci on a human plasma plate after 48 hours' incubation at $37^{\circ} \mathrm{C}$. Strains 25,63 , and 121 are also fibrinolytic.

factory results. Chloroform-treated plasma and sera were tested in these experiments to observe the effect of free plasmin on the coagulase reaction, and soybean inhibitor was introduced to distinguish between fibrinolysis by plasmin and by staphylococcal protease. It was noted that the addition of soybean inhibitor, by preventing the subsequent lysis of coagulase zones, was a useful addition to the mixtures of plasma or serum and bovine fibrinogen.

The results of the "fibrinolysin" plates are set out in Table II. It will be seen that pretreatment

TABLE I

“COAGUlase" Plates POURED AT $45^{\circ} \mathrm{C}$.

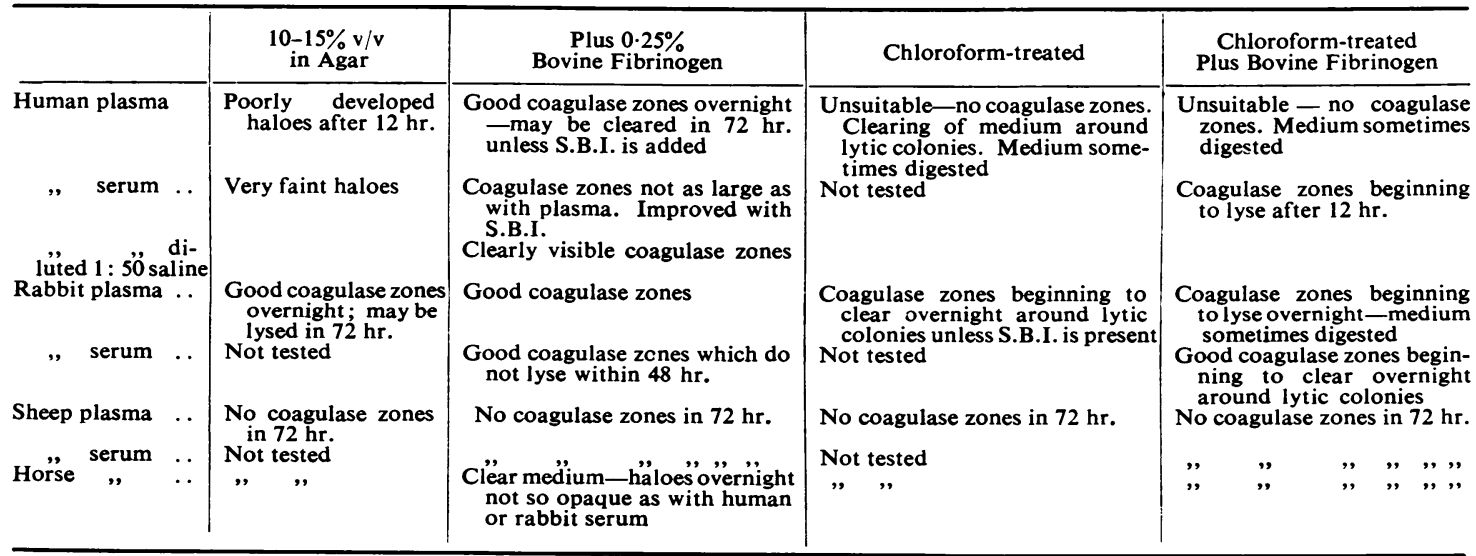


TABLE II

“FIBRINOLYSIN" PLATES POURED AT $56^{\circ} \mathrm{C}$.

\begin{tabular}{|c|c|c|c|c|c|}
\hline & & $\begin{array}{l}10-15 \% v / v \\
\text { in Agar }\end{array}$ & $\begin{array}{l}\text { Plus } 0.25 \% \\
\text { Bovine Fibrinogen }\end{array}$ & $\begin{array}{l}\text { Chloroform- } \\
\text { treated }\end{array}$ & $\begin{array}{l}\text { Chloroform-treated } \\
\text { Plus Bovine Fibrinogen }\end{array}$ \\
\hline \multicolumn{2}{|l|}{ Human plasma } & $\begin{array}{l}\text { Slight lysis between } \\
24-72 \mathrm{hr} \text {. }\end{array}$ & $\begin{array}{l}\text { Slight lysis between } 24-72 \mathrm{hr} \text {. } \\
\text { inhibited by S.B.I. }\end{array}$ & $\begin{array}{l}\text { Wide zone of lysis reduced by } \\
\text { S.B.I. Medium may be } \\
\text { digested }\end{array}$ & $\begin{array}{l}\text { Wide zone of lysis reduced } \\
\text { by S.B.I. Medium may } \\
\text { be digested }\end{array}$ \\
\hline , serum & & Not tested & Slight lysis in $24 \mathrm{hr}$. better than & Not tested & $\begin{array}{l}\text { Wide zones of lysis overnight } \\
\text { inhibited by S.B.I. }\end{array}$ \\
\hline Rabbit plasma & . & $\begin{array}{l}\text { Wide zones of clear- } \\
\text { ing in } 24 \mathrm{hr} \text {. }\end{array}$ & $\begin{array}{l}\text { Wide zones of clearing in } 24 \mathrm{hr} \text {. } \\
\text { inhibited by S.B.I. }\end{array}$ & $\begin{array}{l}\text { Medium cleared and softened- } \\
\text { sometimes digested }\end{array}$ & $\begin{array}{l}\text { Wide zone of lysis reduced } \\
\text { by S.B.I. Medium may } \\
\text { be digested }\end{array}$ \\
\hline $\begin{array}{l}\text { Sheep plasma } \\
\text {,, serum }\end{array}$ & $\begin{array}{l}\cdots \\
\cdots\end{array}$ & $\begin{array}{l}\text { Not tested } \\
\text { No lysis in } 72 \mathrm{hr} . \\
\text { Not tested }\end{array}$ & $\begin{array}{l}\text { Feeble lysis in } 48 \mathrm{hr} \text {. } \\
\text { No lysis in } 72 \mathrm{hr} \text {. }\end{array}$ & $\begin{array}{l}\text { Not tested } \\
\text { No lysis in } 72 \mathrm{hr} \text {. } \\
\text { Not tested }\end{array}$ & $\begin{array}{l}\text { Moderate lysis overnight } \\
\text { Not tested } \\
\text { Slight lytic zones after } 24 \mathrm{hr} \text {. }\end{array}$ \\
\hline Horse , , & $\cdots$ & , , , & No clearing & " " & No clearing \\
\hline
\end{tabular}

S.B.I. = Soybean inhibitor.

of human or rabbit plasma with chloroform may lead to the digestion of the medium, so that to prevent waste a sample should be tested for excess plasmin. Apart from this hazard, chloroform treatment gives a much more satisfactory result.

Several strains which did not appear to be fibrinolytic on ordinary plasma or serum-fibrinogen plates became so when the plasma or serum had had their plasmin inhibitor removed by chloroform; similarly lytic strains showed enhanced lysis in the absence of plasmin inhibitor.

\section{Discussion}

So long as production of coagulase is considered to be the most useful indicator of potential pathogenicity there is scope for improving our methods for identifying coagulase-positive staphylococci. Of the various combinations tested to provide a plate test, human or rabbit plasma plus bovine fibrinogen is the most elegant, especially when a trace of soybean inhibitor is added, but human, rabbit, or horse serum serves very well with bovine fibrinogen.

Not much attention has been paid to degrees of fibrinolytic activity among different strains of staphylococci though this is a useful characteristic in epidemiological work.

In a study of many hundreds of strains from hospital infections, it is apparent that the majority produce so little staphylokinase that the inhibitor $\infty$ in most plasmas is sufficient to restrict a rapid $ᄋ$ fibrinolysis; however, there are some strains, $\rightarrow$ perhaps $10 \%$, which do produce rapid fibrinolysis in the presence of normal plasma or serum. It would be worth considering whether these strains $\stackrel{\Phi}{+}$ are more likely to cause secondary haemorrhage $\overrightarrow{0}$ or loss of grafts when contaminating operation $\mathcal{G}$ sites. There is reason to believe that staphylococci activate or produce more than one protease (Cliffton and Cannamela, 1953; Lack and Wailling, 1954). Perhaps it is time that more attention was given to these enzymes.

\section{Summary}

Methods are described for the quick detection of coagulase-producing and fibrinolysin-producing strains of staphylococci.

It is suggested that more attention be given to rapidly fibrinolytic strains.

It is a pleasure to thank Dr. M. Kunitz for his gift of soybean trypsin inhibitor.

\section{REFERENCES}

Christie, R. and Wilson, H. (1941). Aust. J. exp. Biol. med. Sci., 三. $19,329$.

Cliffton, E. E., and Cannamela, D. A. (1953). Blood, 8, 554.

Lack, C. H., and Wailling, D. G. (1954). J. Path. Bact.. 68, 431. 